\title{
Review article: The English Reformation and the Church of Ireland*
}

\author{
HENRY JEFFERIES \\ Ulster University
}

\begin{abstract}
$\mathrm{I}^{\mathrm{n}}$ n The Tablet, in 2002, Christopher Haigh admitted that the 'revisionist' interpretation of the English Reformation, of which he and Eamon Duffy were the foremost proponents, had left historians with a conundrum, 'struggling to find how the impossible came to be, how the strong, successful and effective Catholicism of late medieval England came to be broken ... and by who'. In Heretics and believers, Peter Marshall, one of Britain's greatest Reformation scholars, presents his solution to that conundrum. It is a tour de force that transforms our understanding of, what Marshall himself terms, 'one of the best-known and most widely discussed epochs in English history: the Reformation of the sixteenth century' (p. xi). He takes us beyond the 'revisionist' paradigm of a top-down religious revolution imposed by royal diktat on an unreceptive populace, to address fundamental questions about how people in England actually responded to the religious maelstrom they found themselves in during the sixteenth century. What he reveals is that key elements of what we call the 'Reformation' resonated with many people in England. People made choices about what they believed, and when necessary they adapted their consciences to the changing conditions they lived through, with the result that the "ways and habits of "doing" religion themselves underwent transformative, irreversible change in a crucible of political calculation and of individual initiative and response' (p. xii). In sum, Marshall takes us to the cutting edge of English Reformation studies. The Church of Ireland focuses on the writing of that church's past. Of particular interest for this review is its discussion of Ireland's experiences of the English Reformation.
\end{abstract}

School of Arts and Humanities, Ulster University, henryjefferies@outlook.com

* Heretics and believers: a history of the English Reformation. By Peter Marshall. Pp xix, 652. New Haven and London: Yale University Press. 2017. £20.

The ChURCh OF IRELAND AND ITS PAST: HISTORY, INTERPRETATION AND IDENTITY. Edited by Mark Empey, Alan Ford \& Miriam Moffitt. Pp xii, 322. Dublin: Four Courts Press. 2017. £50/€55.

Christopher Haigh, 'So why did it happen?' in The Tablet (20 Apr. 2002), p. 11. The key 'revisionist' texts are Christopher Haigh (ed.), The English Reformation revised (Cambridge, 1987); idem, English reformations: religion, politics and society under the Tudors (Oxford, 1993); Eamon Duffy, The stripping of the altars: traditional religion in England, 1400-1580 (London, 1992). 
Marshall's 'unapologetic assumption' is that 'the conflicts of the Reformation were indeed principally about religion: that questions of faith were not merely a convenient covering for more fundamental or "real" concerns about political power, social domination or economic assets' (p. xi). He opens the book with a survey of religious beliefs and practices on the eve of the Reformation that is fairly familiar from 'revisionist' accounts of the past three decades, but with caveats offering a radically different perspective. Hence, 'the dynamism of late medieval religion, accelerating not decelerating in the early Tudor decades, encompassed an extraordinary devotional agility, alongside an unexpected, almost imperceptible, but none the less real spiritual fragility' (p. 22). Marshall characterises it as 'alarmingly unregulated', and highlights concerns in some circles about 'a loss of clarity in the presentation of the essential Christian message' ( $\mathrm{pp} 22,28-9$ ). He points to the influence of Christian humanism with its call for a return ad fontes, to the Judeo-Christian scriptures, as against the scholastic theology which underpinned much that was distinctive in late medieval Catholicism.

Marshall comments that 'In the main the early Tudor bishops deserve the positive reputation they have accrued with modern historians.' (p. 78) However, the leaders of the church (successive popes, Cardinal Thomas Wolsey and England's other bishops), all failed to satisfy 'those longing for a clergy-led renewal of the Church in England' (p. 68). He admits that, 'parish clergy come rather well out of early sixteenth century visitation material' (p. 44). He recognises, however, that 'optimistic generalizations about overall popular "satisfaction" with the clergy risk skating too quickly over the aspirations and frustrations of key constituencies' (p. 46). The church's courts functioned effectively, but 'if rivalry between the practitioners of canon and common law was not ruthlessly unremitting, it was nonetheless fairly endemic, and growing rather than lessening in intensity' (p. 83). Ominously for the church leaders, Henry VIII's stance in that contest was shaped by his very elevated notion of his own 'imperial' authority. Marshall accepts that England's monks, nuns and friars were not guilty of 'depravity, decadence and dissipation' (p. 54). At the same time, he comments on the weakness of their position: 'Yet a culture of contentment and complacency, and a relative deficit of charismatic leadership, left the religious houses, the wealthiest and most institutionally exposed sector of the English Church, ill-prepared to play much more than a passive, on-looking role when the world they had known began, suddenly, to shift on its axes.' (p. 58) He notes that, 'negative stereotypes of monks and friars circulated widely in late medieval England' (p. 63), and he allows more significance to pre-Reformation anti-clericalism than Haigh admitted. ${ }^{2}$ Again, while Marshall concurs with recent work that has shown that the Lollards were few in number and limited in influence, nonetheless he argues that they matter because they remind us that 'the boundaries between orthodoxy and dissent, though at times vigilantly guarded, were also profoundly permeable', because they suggest that the official definitions of theologians 'were not unquestioningly accepted', and because they reveal that the Church's institutional machinery lacked the capability to impose complete uniformity of belief and practice, even against a very small minority of dissidents (p. 119). He continues: 'Most of all, Lollardy's existence, and

Christopher Haigh, 'Anticlericalism and the English Reformation' in idem (ed.), English Reformation revised, pp 56-74. 
persistence, reveals the capacity of ordinary men and ordinary women, orthodox and heretic alike, to think seriously and deeply about issues of conscience and belief.' (p. 119) In effect, Heretics and believers argues that for all of the evidence of good order in the church, and the popularity of its teachings, it was vulnerable nonetheless to a range of challenges, not least of all a general longing for renewal that it failed to satisfy.

The chapter on 'Conversions', is the cornerstone of this book. Marshall reminds us that, "the first "Protestants" were in fact sixteenth-century Catholics' (p. 158). He notes that "The earliest proponents of "the gospel" were not outsiders, but insiders exhibiting some of the best qualities of late medieval piety.' The critical role of highly-regarded individuals, very often priests and friars, in persuading others to change their religious views is emphasised. The 'gospellers' bore 'traditional marks of Catholic holiness' (p. 143). 'What they were saying, and how they said it, resonated in challenging ways with what Catholic Christians already understood to be true' (p. 144). The role of the Lollards is considered, but not exaggerated: 'The early Reformation in England had a sympathetic Lollard godmother, but its parents were orthodox and Catholic.' (p. 140)

Even while the number of 'Lutherans' in England was small, the controversies sparked by Luther were being widely discussed from c.1520. However, the publication in 1526 of William Tyndale's translation of the New Testament in English was 'a game changer' (p. 133). Though Tyndale's translation was illegal, and anyone possessing it was liable to punishment, literally thousands of English Catholics made up their own minds and chose to acquire and read the scriptures in the vernacular. It was something of a Trojan horse for as Tyndale, a former Catholic priest who had embraced Lutheranism, made clear, there was no biblical sanction for key doctrines of the medieval Church, regarding purgatory for instance, nor for elaborate and expensive ecclesiastical institutions that seemed far removed from the ministry of Jesus. What made Tyndale so dangerous to the Catholic church in England was that he was representative of an important strand of late medieval English piety, with its Christocentric focus, its attraction to the scriptures, and its longing for deep spiritual renewal: his message appealed to many earnest Catholics since he had been one of them.

English evangelicals played a pivotal role in what became the English Reformation: "from the very start of life, the English Reformation as an "act of state", and the English Reformation as a spiritual movement, were not remote and distant cousins; they were conjoined twins, dependent, sometimes resentfully, one upon the other' (p. 176). Marshall deftly handles Henry VIII's convoluted contributions to religious changes from the late 1520s. The king insisted on obedience and uniformity in religion, but 'with limited means of coercion at the government's disposal it was vital not merely to command but to persuade' (p. 200). Parliament, pulpits and the printing presses were deployed accordingly to disseminate propaganda. As Marshall notes 'Henry wanted his people to travel with him, but the destination was bafflingly uncertain. His theology was a moving target, a work in progress, a nest of contradictions' (p. 295). The end result, Marshall concludes, was that Henry VIII's 'destructive abolition of old pieties ... in the absence of coherent or compelling alternatives emanating from the crown' meant that 'the English people increasingly worked out for themselves what, and how, to believe' (pp 302, 266).

Evangelicals transformed the Church of England systematically in Edward VI's reign. Yet the authorities struggled hard to keep control of developments. 
The abolition of the heresy laws and the lifting of censorship led to England being flooded with Protestant books, some of them radical. There was a theological ferment: 'the quiet of England was descending into raucous tumult, and thousands of little John Nobodies, in every part of the realm, rose and demanded their say' (p. 327). Dissent from the official Reformation, authorised in the boy-king's name, was expressed not only in words; there were widespread rebellions prompted by 'a potent blend of religion and economic grievance' (p. 331). A more common response to the official Reformation was to boycott the new church services. Rebellions and boycotts were to feature among Irish responses to Elizabeth's Reformation in due course.

For Marshall, Mary's reign was the 'central crux and crisis' of the Reformation. ${ }^{3}$ It 'helped to clarify issues at stake and sharpen confessional identities'. ${ }^{4}$ He reckons that 'the intractableness of conservative forces looks if anything greater after the bracing experience of restored Catholicism'. He discovered too that, persecution 'purified English Protestantism', by uniting Protestants behind the Book of Common Prayer 'to resist the onslaught of Antichrist' (p. 407). 'Elizabeth's Protestantism was of a distinctly wilful and wayward kind' (p. 446), and it comes as no surprise that her subjects were very divided about her religious settlement. Throughout her reign she faced down religious challenges from all directions. By the 1580s, though, most English people were 'Prayer Book Protestants'. 'At the very end of the sixteenth century, Elizabeth's idiosyncratic version of Protestantism received powerful intellectual validation' through 'Richard Hooker's Laws of ecclesiastical polity ... the origins of what would later be called "Anglicanism" (p. 575). Nonetheless, the English Reformation had taught men and women to take 'responsibility for their own understanding of religious truths' (p. 302).

While English Reformation studies have progressed significantly with Peter Marshall's magisterial tome, in The Church of Ireland, James Murray claims that Irish Reformation studies have regressed 'full circle' to a point 'barely distinguishable from that which existed half a century ago, when Brendan Bradshaw began his investigation of George Browne's career' (p. 285). This reviewer is accused, in a footnote, of having an 'unrestrained determination to reconstitute a pre-Bradshaw explanation of the Reformation's failure in Ireland' (p. 285, n. 57). That is rather hyperbolic. ${ }^{5}$ I have no interest in reconstituting any explanation of the failure of the Reformation in Ireland. In fact, because there was no 'Irish Reformation' as such, simply the extension

Peter Marshall, 'Confessionalization, confessionalism and confusion in the English Reformation' in Thomas Mayer (ed.), Reforming Reformation (Farnham, 2012), p. 15.

Peter Marshall, Reformation England, 1480-1642 (London, 2003), p. 111. The same was broadly true of Ireland, See: Henry Jefferies, 'The Marian restoration in Ireland' in British Catholic History, xxxiii, no. 1 (May 2016), pp 12-31.

Murray's characterisation can be contrasted with reviews of The Irish Church and the Tudor reformations (Dublin, 2010) by, for example, Peter Marshall (Times Literary Supplement, 30 Sept. 2011, p. 22); Steven Ellis (Journal of British Studies, 1, no. 3 (July 2011), pp 729-30); Felicity Heal (Journal of Ecclesiastical History, 1xii, no. 4 (Oct. 2011), pp 831-2); Colm Lennon (British Catholic History, 1, no. 3 (May 2011), pp 50305); Mary Ann Lyons (Parliamentary History, xxxi, no. 2 (June 2012), pp 238-9; W.M. Spellman (Sixteenth Century Journal, xlii, no. 4 (Winter 2011), pp 1197-9). For my assessment of the question of failure, see 'Why the Reformation failed in Ireland' in I.H.S. xl, no. 158 (Nov. 2016), pp 151-70. 
to Ireland of the religious policies of a series of Tudor monarchs, I believe that the Reformation in Ireland is best understood within a wider Tudor or English framework. I share English Reformation scholars' 'axiomatic assumption' about the importance of religion in the lives of men and women in the sixteenth century, their interest in the processes of conversion, and the ways in which people responded to the Reformation, whether by embracing it, acquiescing in it, or by demonstrating their dissent from it, passively or more actively, including through rebellion. Murray complains that I sometimes use evidence 'which laments the obdurate nature of Irish religious conservatives, and the feeble condition of the established church' (p. 285). In response, I can only plead that historians are obliged to make use of the evidence that is available, and the consistency of the evidence in question, from English contemporaries and Irish, Catholics and Protestants, churchmen and laymen, is both considerable and compelling.

This 'English' perspective has revealed significant commonalities, not simply between the pre-Reformation church and religion in England, and at least the more anglicised parts of Ireland, but also in the Reformation experiences of people on either side of the Irish Sea. ${ }^{6}$ The progress made in the implementation of the Tudors' religious policies in Ireland has been assessed in relation to the progress made elsewhere in the Tudor domains, and has been shown to have been very significant. However, in striking contrast with England, the Tudors' 'act of state' reformations in Ireland did not coincide with the growth of communities of local evangelicals/Protestants: the clear corollary is that the absence of local support inhibited the progress of the Reformation in Ireland compared with England. Elizabeth's Reformation encountered extraordinary resistance in Dublin and the Pale from the start. There was a general boycott of Book of Common Prayer services, and disruptions by those forced to attend against their wills, that obliged the queen to establish the Irish Ecclesiastical High Commission as early as 1564 . However, the commission only succeeded in imposing some spasmodic outward conformity on a sullen population. Coercion did not lead to conversion in the absence of proponents of the Reformation in the parishes. The local elites attended Mass 'continually', employed Catholic chaplains and tutors, and a growing number sent their sons to Catholic colleges on mainland Europe.

Yet, the rejection of Protestantism did not ensure the survival of Catholicism:'only when the Catholic Church in Ireland was reorganised on a sustainable footing as a disestablished "people's church" in the 1580s, and infused with the confidence inspired by the Counter Reformation, can the Reformation be stated to have failed in Ireland definitively., ${ }^{8}$ Steven Ellis, in an invariably learned essay, opines that if 'the resources had been provided and

${ }^{6}$ This is made explicit in Henry Jefferies, 'The early Tudor reformations in the Irish Pale' in Journal of Ecclesiastical History, lii, no. 1 (Jan. 2001), pp 34-62; idem, 'Elizabeth's Reformation in the Irish Pale' in Journal of Ecclesiastical History, lxvi, no. 3 (July 2015), pp 524-42; idem, 'Tudor reformations compared: the Irish Pale and Lancashire' in Christopher Maginn and Gerald Power (eds), Frontiers, states and identity in early modern Ireland and beyond (Dublin, 2016), pp 71-92.

Jefferies, The Irish church, chapter 7; idem, 'Elizabeth's Reformation in the Irish Pale', pp 524 42.

Jefferies, 'Why the Reformation failed in Ireland', p. 170. The progress of the Elizabethan Reformation across Ireland is traced in detail in Jefferies, The Irish church, chapters $7-10$. 
coercion applied on sufficient scale over a long enough period, this failure of the Reformation could have been reversed' (p. 265). However, neither the Tudors nor the Stuarts had sufficient resources to make such a strategy feasible, and the belief in 'double predestination' prevalent among British Protestants made such a mechanistic strategy anathema in any case.

The failure of the Reformation cast a long shadow over the Church of Ireland. It secured many of the physical endowments and financial prerogatives of the late medieval Irish Church, but not its congregations: contemporaries estimated the number of Irish Protestants at between forty and 120 by the end of Elizabeth's reign. ${ }^{9}$ A recurring theme in several of the essays in The Church of Ireland is the struggle of its historians to justify its claims to be the Irish church, and its entitlement to the considerable privileges it enjoyed as the established Church, not least of all to tithes, despite enjoying the support of a small minority of the population of Ireland. ${ }^{10}$ Central to the historiography of the Church of Ireland was what Miriam Moffitt terms, 'the Ussherian template of Irish Church history' (p. 182). In 1631 James Ussher challenged the prevailing understanding of the Church of Ireland as an 'offshoot, or even a part of the Church of England', and represented it instead as 'an independent entity, with strong Irish roots' (p. 26). He side-stepped the uncomfortable fact that the Irish people of his own day had rejected the Reformation by claiming that the Church of Ireland was the Irish Church because it was true to 'the religion anciently professed by the Irish'. He bolstered the Church of Ireland's claims to the 'medieval heritage' of the church in Ireland by encouraging James Ware to graft the names of Protestant bishops onto lists of their pre-Reformation predecessors, without any acknowledgement of the disruptions caused by the Tudors' reformations (pp 41-2, 48, 62). The exclusivist claims of the Church of Ireland about the 'Celtic church' and episcopal succession long rankled Irish Catholics and Presbyterians. Moffitt observes that even in the monumental History of the Church of Ireland, published in 1933-4, 'Ussher's vision of the Protestant history of Ireland was still alive' (p. 193).

The over-riding impression left by The Church of Ireland is that until recently most church history was a form of apologetics, with some rare exceptions as Dáibhí Ó Cróinín and Thomas O’Loughlin show was the case in the work of J. H. Todd and William Reeves respectively. Ian d'Alton discusses the professionalisation of church histories since 1950, but wonders whether the result is a 'rather incestuous discussion between academics' as against an engagement with the wider world, and whether in any case 'that wider world knows and cares little about the history of the religious past anyway' (p. 235). On the other hand, if the publication of new titles is anything to judge by, the English Reformation retains its fascination for a wide audience, and Marshall's Heretics and believers makes it even more fascinating than ever.

"Henry Jefferies, " "Revisionism" in Tudor reformation studies' in I.H.S., xxxviii, no. 152 (Nov. 2013), p. 695.

The census of 1861 showed that Anglicans comprised just 12 per cent of the population of Ireland: James Golden, 'Irishness, foreignness and national identity: apostolic succession in disestablishment historiography' in Empey, Ford \& Moffitt, (eds)The Church of Ireland, p. 144. 